\title{
A new species of Lepidopteris discovered from the Upper Permian of China with its stratigraphic and biologic implications
}

\author{
ZHANG Yi ${ }^{1 *}$, ZHENG ShaoLin ${ }^{1} \&$ NAUGOLNYKH Serge $\mathrm{V}^{2}$ \\ ${ }^{1}$ College of Paleontology, Shenyang Normal University, Shenyang 110034, China; \\ ${ }^{2}$ Geological Institute, Russian Academy of Sciences, Moscow 119017, Russia
}

Received March 21, 2012; accepted May 11, 2012; published online July 2, 2012

\begin{abstract}
A new species Lepidopteris baodensis sp. nov. belonging to the family Peltaspermaceae and represented by two ultimate pinnae in the collection under study, was recently discovered at the Baijiagou of Baode, Shanxi, China, from the Upper Permian Sunjiagou Formation. The lower surface of the ultimate rachis, the midrib and secondary veins is covered with triangular, trapezoid, rounded, or ligulate subepidermal swellings, which show different natures from intercalary pinnules. Lepidopteris is one of typical elements of the Late Permian Euramerican flora. Since Schimper erected the genus Lepidopteris in 1869, the entire epidermal structure of subepidermal swellings had been unclear. The new species L. baodensis clearly showing the distinguished epidermal structure of subepidermal swellings, not only enlarges and supplements our knowledge in biology and taxonomy of Lepidopteris as well as the Upper Permian stratigraphy of China, but also provides an opportunity to understand the relationship between Euramerican floras and Cathaysian floras in paleoclimatic, paleoenvironmental and paleogeographic context.
\end{abstract}

Lepidopteris baodensis, subepidermal swellings, epidermal structure, the Upper Permian, Cathaysian floras, paleoclimate

Citation: Zhang Y, Zheng S L, Naugolnykh S V. A new species of Lepidopteris discovered from the Upper Permian of China with its stratigraphic and biologic implications. Chin Sci Bull, 2012, 57: 3603-3609, doi: 10.1007/s11434-012-5282-0

Lepidopteris, Antevsia, and Peltaspermum as the generic names are used for the leaves, pollen organs and seed organs respectively, belonging to representatives of the family Peltaspermaceae [1]. Lepidopteris is characterized by the bipinnate or tripinnate fronds with the rachis covered with small subepidermal swellings; pinnules thick and intercalary pinnules present; veins often unclear; stomata amphistomatic [1-4].

Although it is thought to be the genus from the Upper Permian to the Upper Triassic in Europe [1], the genus Lepidopteris represented by only one species L. martinsii (Germar) Townrow found in the Upper Permian of China, was also attributed to Callipteris $[5,6]$. The species L. ottonis was considered to be an index fossil for the Upper Triassic in China [3]. A new species L. baodensis sp. nov., represented by two ultimate pinnae, has recently been discovered from the Upper Permian Sunjiagou Formation at

*Corresponding author (email: zhangyihzlmh@synu.edu.cn) the Baijiagou of Baode, Shanxi, North China (Figure 1(a)(d)).

\section{Materials and methods}

The Sunjiagou Formation is about 200 m thick, predominately consists of light yellow or grey pebbled sandstones, purple mudstones intercalated with grey green sandstones, and grey white feldspathic quartzose sandstones (Figure 1(c)).

Two fossil specimens studied were found in the dark shale lens within sandstones, about $1 \mathrm{~km}$ east to Baijiagou $\left(111^{\circ} 05^{\prime} 12^{\prime \prime} \mathrm{E}, 38^{\circ} 46^{\prime} 02^{\prime \prime} \mathrm{N}\right)$ (Figure 1(b)-(d)). The associated fossil plants include Cathaysiodendron, Taeniopteris, Supaia and Noeggerathiopsis [7]. One specimen (PMOLB01216) is preserved as compression (Figure 2(a)) with the cuticles (Figure 2(c)); the other (BD139-0801) is only preserved as the cuticles (Figure $2(\mathrm{~g})$ ). The cuticles of the upper and lower surfaces (specimen PMOL-B01216) were 

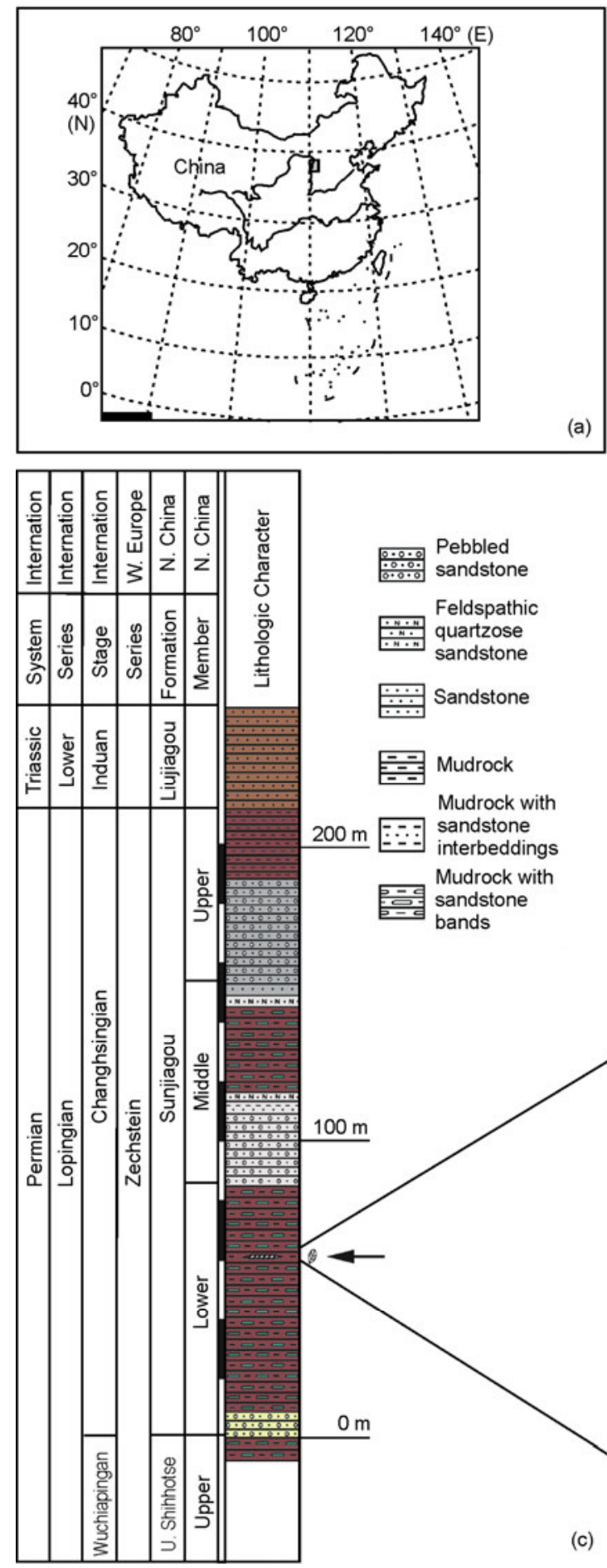

(a)

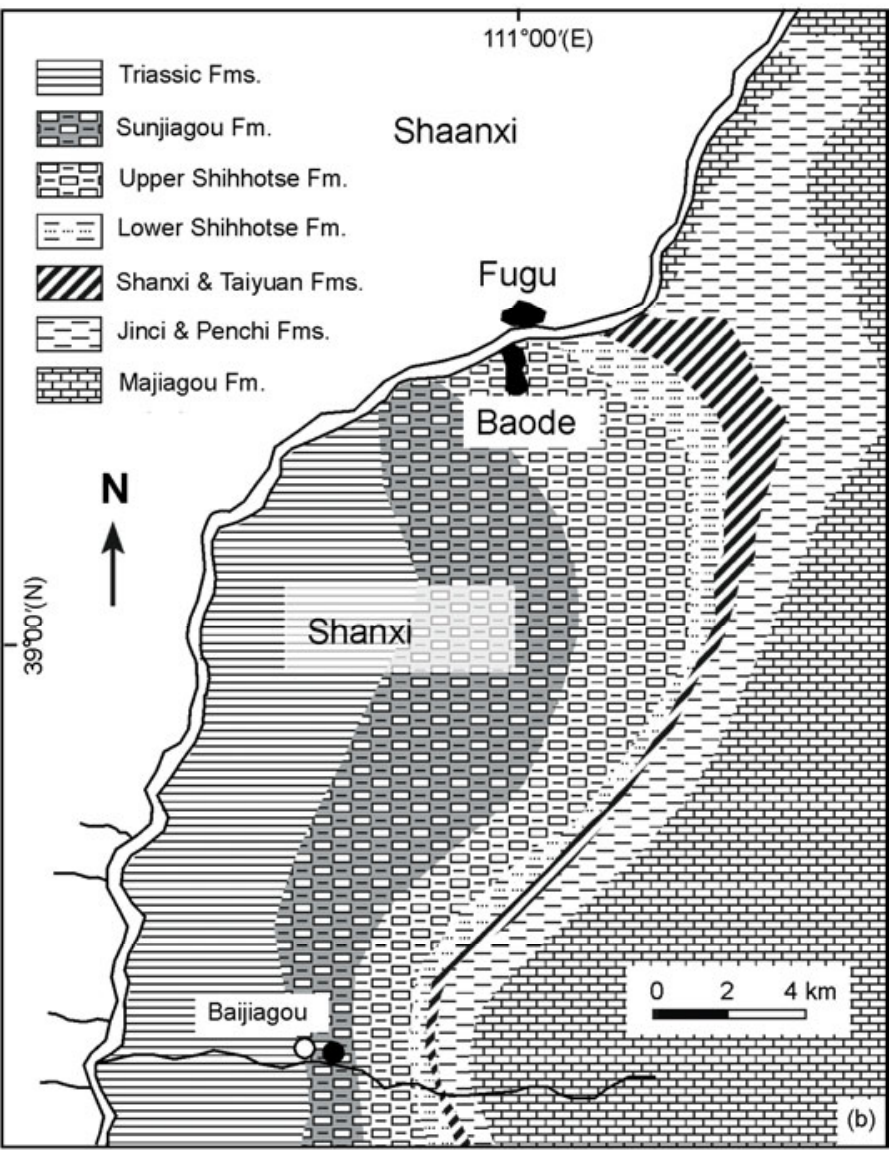

Figure 1 The location of the study area where Lepidopteris baodensis sp. nov. was found. (a) The geographic map of China. Scare bar: 1:10 ${ }^{8}$; (b) the geologic map of Baode [7], enlargement of the frame in (a). The black dot indicates the fossil site; (c) the stratigraphic column of the Sunjiagou Formation in the Baijiagou of Baode [7]. The arrow shows the bed yielding L. baodensis sp. nov.; (d) the locality where the specimens of L. baodensis sp. nov. were collected.

separated after they were treated by nitric acid (Figure 2(e)-(f)). Cuticles were studied with the light microscope BM2000 made by NJYO, China. The morphology of papil- lae was further checked by SEM JSM-6700 made by JEOL, Japan. Specimens are housed at the College of Paleontology, Shenyang Normal University. 

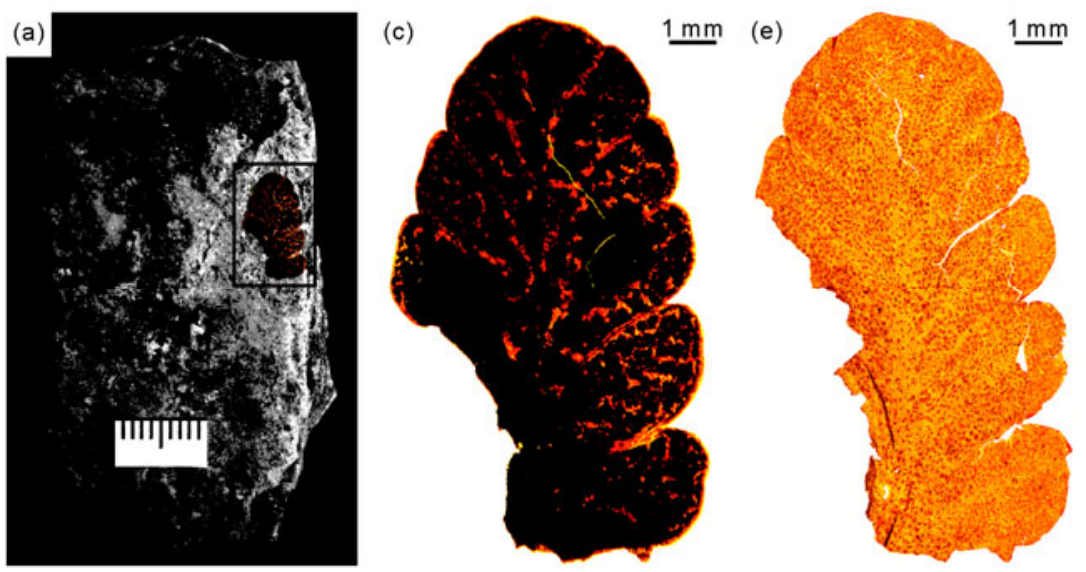

(g)
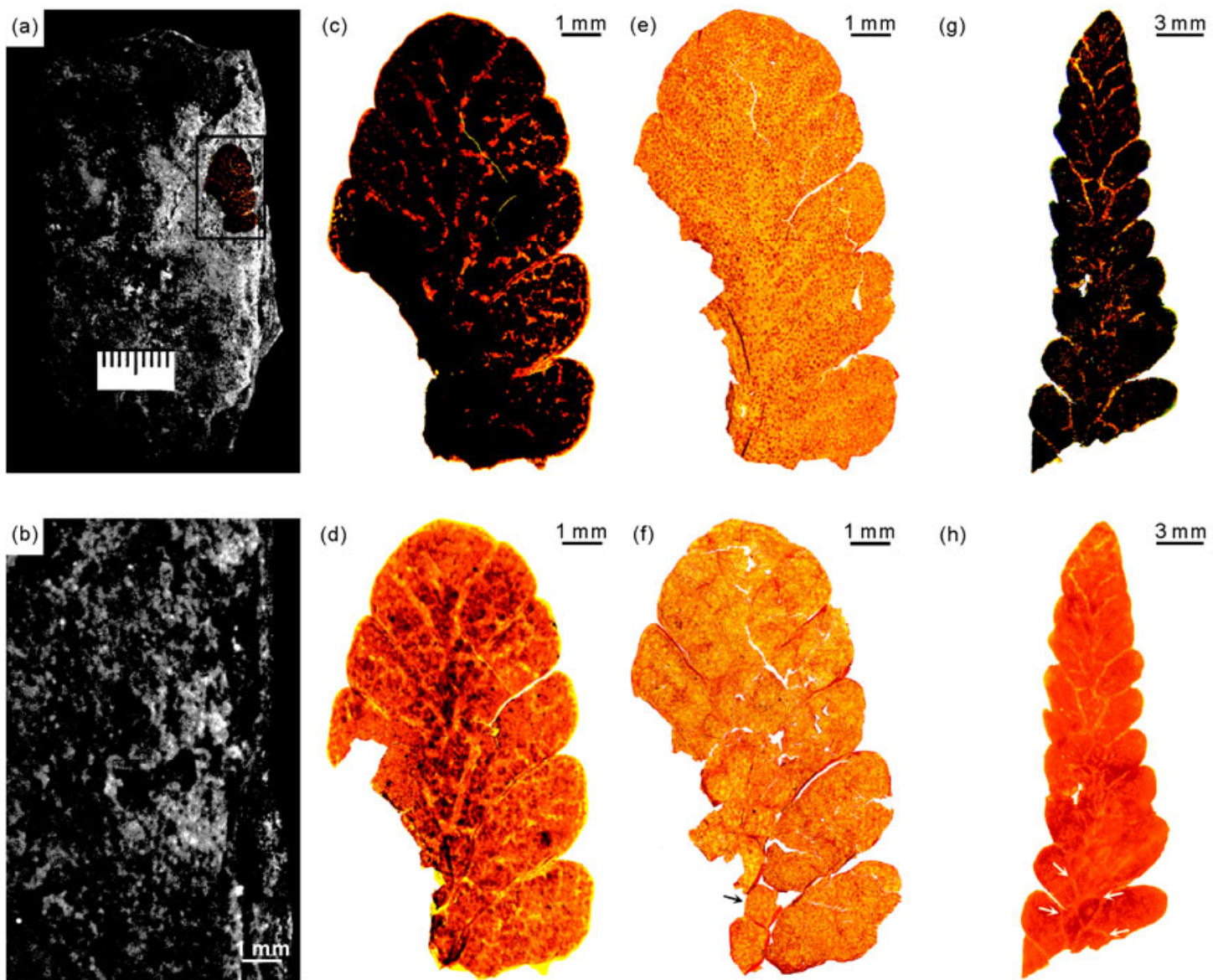

(h)

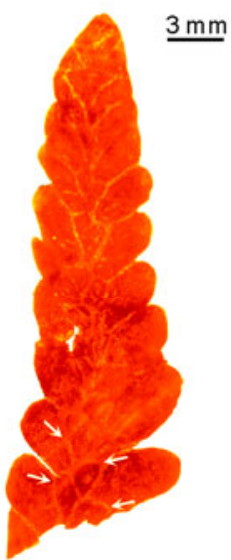

Figure 2 Specimens of Lepidopteris baodensis sp. nov. (a)-(f) Specimen PMOL-B01216. (a) The specimen preserved as compression with the cuticles (frame); (b) enlargement of the frame in (a) after the cuticles were taken away; (c) enlargement of the cuticles before nitric acid treatment; (d) enlargement of the cuticles after $20 \%$ nitric acid treatment; (e), (f) enlargements of the cuticles of the upper and lower surfaces, respectively. The cuticles of the upper and lower surfaces were separated after $40 \%$ nitric acid treatment. The arrow shows a subepidermal swelling occurring on the ultimate rachis. (g), (h) Specimen BD139-0801. (g) The specimen preserved as the cuticles; (h) the cuticles after 40\% nitric acid treatment. Arrows show subepidermal swellings occurring on the ultimate rachis.

\section{Results}

Peltaspermopsida

Peltaspermales

Peltaspermaceae

Genus Lepidopteris Schimper, 1869

Type species Lepidopteris stuttgartiensis (Jaeger) Schimper, 1869

Lepidopteris baodensis Zhang, Zheng et Naugolnykh sp. nov.

Etymology: The specific epithet is named after the Baode locality, Shanxi, North China.

Holotype: The specimen No. PMOL-B01216.

Occurrence: Baode, Shanxi, North China; Sunjiagou Formation (the Upper Permian).

Diagnosis: The ultimate pinna lanceolate. Pinnules thick, oblong to falcate with an obtuse apex and a decurrent base. Midrib decurrent. Secondary veins simple. The upper surface of the ultimate rachis, the midrib and secondary veins smooth, while the lower surface of them covered with triangular, trapezoid, rounded, or ligulate subepidermal swellings. Epidermal cells polygonal with prominent papillae, lacking trichome or trichome bases. Leaves amphistomatic. The stomata are more numerous on the lower surface of the leaf. Stomatal apparatus haplocheilic, monocyclic to polycyclic.

Description: The ultimate pinna is lanceolate, about 3 $\mathrm{cm}$ long and $1 \mathrm{~cm}$ wide, gradually narrowing to the obtuse apex (Figure 2(h)). The upper surface of the ultimate rachis is smooth (Figure 2(e); Figure 3 (a)), while the lower surface of the ultimate rachis is covered with triangular, trapezoid, or ligulate subepidermal swellings (Figure 2(d), (f)), more or less paired, attaining a maximum length of at least $3 \mathrm{~mm}$ long, $1.5 \mathrm{~mm}$ wide (Figure 2(h), arrows). Pinnules are thick, oblong to falcate, attaining a maximum length of at least $6 \mathrm{~mm}$ long and $3 \mathrm{~mm}$ wide, alternate, asymmetrical, attaching to the axial area of the pinna at an angle of $30^{\circ}-50^{\circ}$. The pinnule bases are decurrent, lateral margins 

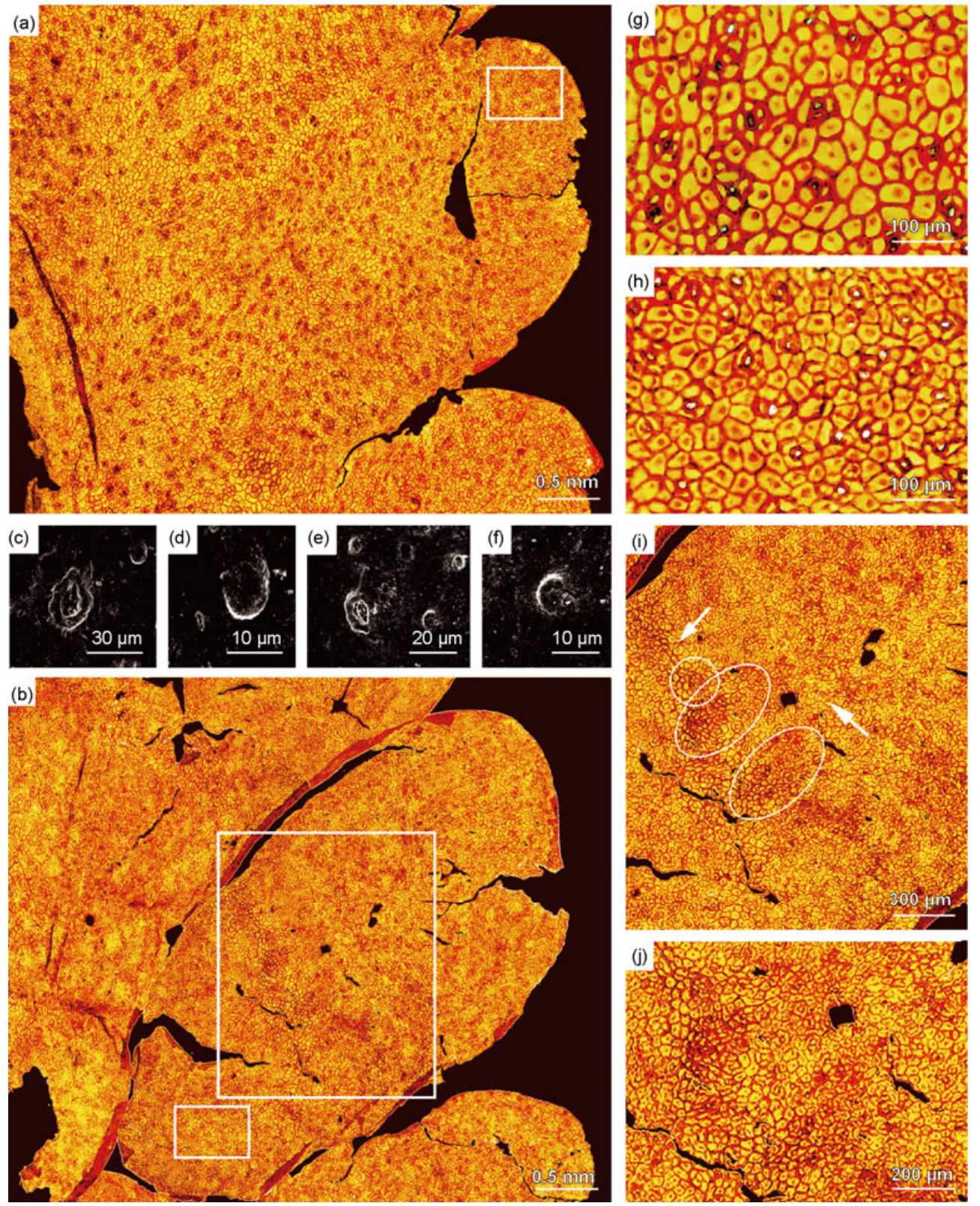

Figure 3 Cuticles of Lepidopteris baodensis sp. nov. Specimen PMOL-B01216. (a), (b) Cuticles of the upper and lower surfaces, enlargements of Figure 2 (e) and (f), respectively; (c), (e) stomatal apparatus and papillae on the upper and lower surfaces, respectively; (d), (f) enlargements of (c) and (e), respectively; (g), (h) enlargements of the frames in (a) and (b) (lower frame), respectively; (i) enlargement of (b) (upper frame), showing subepidermal swellings (middle and lower circles) disposed on the midrib (lower arrow) and a subepidermal swelling (upper circle) developed on the secondary vein (upper arrow); (j) enlargement of (i).

parallel and apices obtuse. Midrib is decurrent, bending slightly forward. The upper surface of the midrib is smooth (Figure 3(a)), while the lower surface of the midrib is covered with triangular, rounded to ligulate subepidermal swellings, single or paired, generally $300-500 \mu \mathrm{m}$ in length, $300-400 \mu \mathrm{m}$ in width (Figure 3(i), (j)). Secondary veins are arched or straight, simple. The upper surfaces of secondary veins are smooth (Figure 3(a)), whereas the lower surfaces of secondary veins are sometimes developed triangular to rounded subepidermal swellings, single, generally 200-300 $\mu \mathrm{m}$ in length, $150-200 \mu \mathrm{m}$ in width (Figure 3(i), (j)).
The upper epidermis and the lower epidermis are different. Stomata are amphistomatic. The stomata are more numerous on the lower surface of the leaf. The upper ordinary epidermal cells are polygonal, about $40-80 \mu \mathrm{m}$ in length, $25-40 \mu \mathrm{m}$ in width (Figure 3(g)), with prominent papillae, 9-10 $\mu \mathrm{m}$ in diameter (Figure 3(d), (g)). Anticlinal walls are generally straight, occasionally arched. Stomatal apparatus are haplocheilic, monocyclic to polycyclic, about 45 per $1 \mathrm{~mm}^{2}$ (Figure 3(a), including areas of the pinnule and the ultimate rachis). Stomata are irregularly oriented. Guard cells are sunken, cutinized at the surface. Subsidiary cells 
are polygonal, generally 4-5 in number (Figure 3(g)).

The lower ordinary epidermal cells are polygonal, generally $30-50 \mu \mathrm{m}$ in length, $15-30 \mu \mathrm{m}$ in width (Figure $3(\mathrm{~h})$ ), with prominent papillae, 6-7 $\mu \mathrm{m}$ in diameter (Figure 3(f), (h)). Anticlinal walls are either straight or arched. Stomatal apparatus are haplocheilic, monocyclic to polycyclic, about 100 per $1 \mathrm{~mm}^{2}$ (Figure 3(b), including areas of the pinnule and the ultimate rachis). Stomata are irregularly oriented. Guard cells are sunken, slightly cutinized at the surface. Subsidiary cells are polygonal, generally 4-5 in number (Figure 3(h)).

The epidermis of a subepidermal swelling on the ultimate rachis is composed of ordinary epidermal cells and stomatal apparatus, forming longitudinal files (Figure 4, arrows) and numerous groups (Figure 4, circles). Ordinary epidermal cells and stomatal apparatus in each group set in a concentric pattern. The epidermis of a subepidermal swelling on the midrib is also composed of ordinary epidermal cells and stomatal apparatus, only forming 3-4 groups (Figure 3(i), middle and lower circles; (j)). Ordinary epidermal cells and stomatal apparatus in each group also set in a concentric pattern. The epidermis of a subepidermal swelling on the secondary vein is composed of ordinary epidermal cells and stomatal apparatus, forming a concentric pattern (Figure 3(i), upper circle; (j)).

\section{Discussions}

The upper and lower surfaces of the Lepidopteris baodensis sp. nov. pinna are markedly different in structure (Figures 2(e), (f); 3(a), (b); S1 and S2). Their colors are also different. The upper surface is darker than the lower surface (Figure 2(e), (f)). Based on the lightness and saturation of the cuticles, the upper surface has lower lightness and higher saturation, while the lower surface has higher lightness

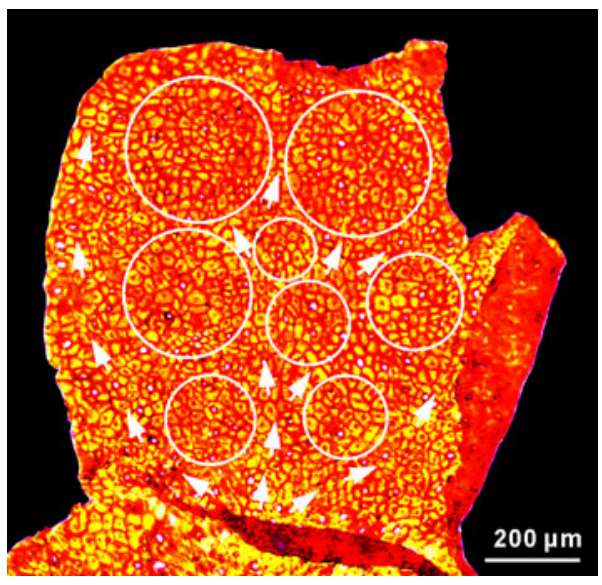

Figure 4 Cuticle of a subepidermal swelling on the ultimate rachis of Lepidopteris baodensis sp. nov., enlargement of Figure 2(f) (arrow), showing a subepidermal swelling on the ultimate rachis. Arrows show longitudinal files, while circles indicate groups with a concentric pattern. Specimen PMOL-B01216. and lower saturation. The reconstruction based on the holotype morphology of specimen PMOL-B01216 shows in Figure 5, including the upper and lower surfaces of an ultimate pinna.

Subepidermal swellings on the rachis were described as blisters [1]. It is recommended to use "subepidermal swelling" to replace "blister" because this structure has been interpreted as a "swelling" coming from the area below the epidermis [4].

Lepidopteris belongs to a small succulent pteridosperm [6]. The inside of subepidermal swellings probably develops aqueous tissue. This distinguished structure was suitable for Lepidopteris surviving the climate of desertification in Late Permian.

The natures of a subepidermal swelling are different from an intercalary pinnule in the fact that: (1) the former occurs not only on the ultimate rachis, but also on the midrib and secondary veins, while the later occurs only on the penultimate rachis; (2) the former is developed from the inside tissue below the abaxial (lower) epidermis, while the later is developed from the lateral side of a penultimate rachis; and (3) the morphology of the former is unlike a pinnule, whereas the later belongs to a pinnule.

Although the present specimen lacks intercalary pinnues, it is assigned to the genus Lepidopteris on the basis of the small subepidermal swellings disposed on the axial area of the ultimate pinna. Intercalary pinnules are on the rachis of a penultimate pinna, not on the rachis of an ultimate pinna.

The rachis of Lepidopteris baodensis sp. nov. is covered with triangular to ligulate subepidermal swellings, while imbricate hard rounded scales (as well as the subepidermal swellings) are present on the axial area of $L$. stuttgartiensis [2]. The new species is similar to L. martinsii in the fact that subepidermal swellings present on the rachis, but $L$. baodensis sp. nov. differs from L. martinsii in the absence of trichomes or trichome bases [1]. The morphology of $L$. ottonis and L. strombergensis is comparable to our new species, but their subsidiary cells bear the cutinized papillae in
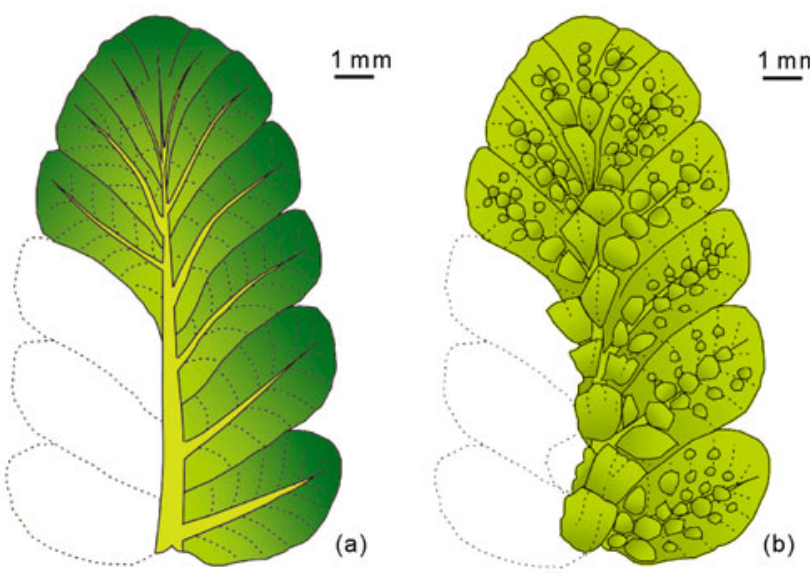

Figure 5 The reconstruction of Lepidopteris baodensis sp. nov. based on Specimen PMOL-B01216. (a) The upper surface of an ultimate pinna; (b) the lower surface of an ultimate pinna. 
L. ottonis and L. strombergensis, while there are solitary trichomes found in L. ottonis [1].

Lepidopteris is compared with Callipteris on the basis of similarity of the amphistomatic leaves, as was noted by Barthel and Haubold [8], but actually Lepidopteris is different from "Callipteris" (now Rhachiphyllum Kerp and the related form-genera) in the existence of the prominent subepidermal swellings disposed on the rachis or axial area of the pinnae. The Late Permian species L. baodensis sp. nov. and L. martinsii, as well as the Triassic species $L$. ottonis and L. strombergensis have subepidermal swellings on the rachis [1]. Callipteris martinsii reported by Wang et Wang [6], is assignable to L. (Peltaspermum) martinsii [9]. The present species is a new record of Lepidopteris in North China based both on macromorphology and cuticular structure of the specimen studied.

In Late Carboniferous, the Cathaysian flora and the Euramerican flora existed completely in the tropical region [10]. The Cathaysian flora represents the vegetation of tropical islands, whereas the Euramerican flora represents the vegetation located in the tropical area of the Pangea supercontinent. The two floras shared some similar elements, such as Lepidodendron, Annularia, Pecopteris, Neuropteris and Cordaites. From Early Permian to Middle Permian, the Euramerican flora was affected by desertification of the climate, while wet tropical climate almost persisted in the regions of the Cathaysian flora during most of the Permian [10]. The gigantopterids, emplectopterids, lobatannularians, tingialeans, fascipterids, Conchophyllum, taeniopterids and oriental lepidophytes became endemic groups of the Permian Cathaysian Flora [11]. The climatic conditions of the two floras became similar again in the Late Permian $[10,12]$. Many elements of the Euramerican flora penetrated into the Cathaysian flora in the Late Permian. The genus Lepidopteris is one of the typical elements of the Euramerican flora [1]. The peltasperms, taxonomically very close to $L$. martinsii and L. baodensis sp. nov. were also described from the Vladimirian stage, the terminal Permian of the European part of Russia [13,14], belonging to the Eurasian arid province [5]. But there are only a few records of Lepidopteris in the Late Permian Cathaysian flora. Lepidopteris can serve as a good example of the plants that migrated from the Euramerica flora to the Cathaysian flora through the Eurasian "gateway". The genus Lepidopteris together with some other elements of the Late Permian Euramerican flora, such as Ullmannia, Pseudovoltzia, Quadrocladus, and Peltaspermum [6], penetrated into the Cathaysian flora. This migration reflects the paleoclimatic and paleoenvironmental changes in the Late Permian Cathaysia.

The discovery of the new Lepidopteris species demonstrates that the stratigraphica distribution of the genus Lepidopteris in China is from the Upper Permian to the Upper Triassic. Because the Earth experienced a mass extinction and recovery from Late Permian to Triassic $[15,16]$, many important taxa were completely or almost extinct before
Early Triassic, such as Cathaysiodendron [17,18], Emplectopteris and Gigantopteris [11]; some taxa were first recorded in Carboniferous, and difficult to be found in Early to Middle Triassic, but thrived at the beginning of Late Triassic, such as Pterophyllum [3,19] and Protophyllocladoxylon [20], while Lepidopteris generally occurred from Late Permian to Late Triassic. As a small succulent pteridosperm with the distinguished structure of subepidermal swellings, Lepidopteris can serve as an important element to understand this significant change from Late Permian to Triassic in geological time.

It is very interesting to find Cathaysiodendron mixed with Lepidopteris in the same fossil site [7]. Cathaysiodendron is usually thought to live in the lower land environment, which is different from Lepidopteris mostly from the upland. Further works need to be done to explain this discovery.

This work was supported by the Project 111 of China (B06008), the Scientific Research Operating Expenses, Jilin University-the Base Platform Construction Project, the National Natural Science Foundation of China (40972001), and RFBR No. 11-05-92692-Ind_a. We are very grateful to Prof. Sun, Key-Lab for Evolution of Past Life \& Environment, MOE (Jilin Univ.) and Prof. Dilcher, NAS, Department of Geology, Indiana University for their careful reviews of this paper as well as the anonymous reviewers for their useful comments. Thanks are extended to Prof. Zhu Huaicheng (NIGPAS) for his help in the stratigraphic column of Baode, Senior Engineer Huang Fengbao (NIGPAS) for her help to study cuticles, as well as Prof. Zhang Wu, Shenyang Institute of Geology \& Mineral Resources and Prof. Na Jie, College of Chemistry and Biology, Shenyang Normal University for their positive suggestions in studying cuticles. Thanks go to Prof. Wang Jun, Prof. Liu Lujun and Senior Engineer Mei Shengwu (NIGPAS), Dr. Tian Ning and Bai Shuchong (PMOL), as well as Mr. Yuan Quansheng, vice director of the Nanhegou of Baode for supporting our excursion in Baode.

1 Townrow J. The Peltaspermaceae, a pteridosperm family of Permian and Triassic age. Palaeontolgy, 1960, 3: 333-361

2 Schimper W P. Traité de paléontologie végétale ou la flore du monde primitif. Volume 1. Paris: Bailliêre J B et Fils, 1869. 572-574

3 Si X J, Li X X. Mesozoic Plant of China Fossil (in Chinese). Beijing: Science Press, 1963. 131-133

4 Taylor T N, Taylor E L, Krings M. Paleobotany-The Biology and Evolution of Fossil Plants. Boston: Academic Press (Elsevier), 2009. 639-650

5 Wang Z Q. Palaeovegetation and plate tectonics: Palaeophytogeography of North China during Permian and Triassic times. Palaeogeogr Palaeoclimatol Palaeoecol, 1985, 49: 25-45

6 Wang Z Q, Wang L X. Late Permian fossil plants from the lower part of the Shiqianfeng (Shihchienfeng) Group in North China (in Chinese). Bull Tianjin Inst Geol Min Res, 1986, 15: 1-80

7 Zhang Y. Late Palaeozoic flora from Baode, Shanxi. Dissertation for the Doctoral Degree (in Chinese). Nanjing: Nanjing Institute of Geology and Paleontology, Chinese Academy of Sciences, 2009. 1-154

8 Barthel M, Haubold H. Zur Gattung Callipteris Brongniart. I: Die Ausbildung von Callipteris conferta (Sternberg) Brongniart im mitteleuropäischen Rotliegenden Schriftenr. Geol Wiss, 1980, 16: 49105

9 Poort R J, Kerp J H F. Aspects of Permian palaeobotany and palynology. XI. On the recognition of true peltasperms in the Upper Permian of Western and Central Europe and a reclassification of species formerly included in Peltaspermum Harris. Rev Palaeobot Palyno, 1990, 63: 197-225 
10 Boucot A J, Chen X, Scotese C R, et al. Global Paleoclimate Reconstruction of Phanerozoic (in Chinese). Beijing: Science Press, 2009. $1-173$

11 Li X X, Shen G L, Tian B L, et al. Some notes on Carboniferous and Permian floras in China. In: Li X X, ed. Fossil Floras of China Through the Geological Ages. Guangzhou: Guangdong Science and Technology Press, 1995. 244-302

12 Wang Z Q, Zhang Z P. Gymnosperms on the eve of the terminal Permian mass extinction in North China and their survival strategies. Chin Sci Bull, 1998, 43: 889-897

13 Naugolnykh S V. Upper Permian flora of Vjazniki (European part of Russia), its Zechstein appearance, and the nature of the Permian/Triassic extinction. The Nonmarine Permian. Bull New Mexico Mus, 2005, 30: 226-242

14 Naugolnykh S V. The Vjaznikovskian flora and the nature of Permian/Triassic extinction. Causal-consequentional connections and factors of the Phanerozoic biospheric reorganization. Trans Geol Inst RAS, 2006, 580: 42-71

15 Rong J Y, Fang Z J. Comparative analysis of the three major palaeo- zoic mass extinctions and their subsequent recoveries in South China. In: Rong J Y, Fang Z J, eds. Mass Extinction and Recovery. Vol. 2. Hefei: University of Science and Technology of China Press, 2004. 1078-1087

16 Saunders A, Reichow M. The Siberian Traps and the End-Permian mass extinction: A critical review. Chin Sci Bull, 2009, 54: 20-37

17 Li X X. Fossil plants of the Yuehmenkou Series, North China. Palaeontologia Sinica, New Series A No. 6. Beijing: Science Press, 1963. $1-185$

18 Zhang Y, Wang J, Wu X Y. Cathaysiodendron yangshanense sp. nov. from the Early Caboniferous Yangshan Formation of Gushi, Henan. Acta Palaeont Sin, 2006, 45: 265-267

19 Sun G, Meng F S, Qian L J, et al. Triassic floras. In: Li X X, ed. Fossil Floras of China Through the Geological Ages. Guangzhou: Guangdong Science and Technology Press, 1995. 305-342

20 Zhang Y, Wang J, Liu L J, et al. Protophyllocladoxylon jingyuanense sp. nov., a gymnospermous wood of the Serpukhovian (Late Mississippian) from Gansu, Northwest China. Acta Geol Sin, 2010, 84: 257-268

Open Access This article is distributed under the terms of the Creative Commons Attribution License which permits any use, distribution, and reproduction in any medium, provided the original author(s) and source are credited.

\section{Supporting Information}

Figure S1 Cuticle of the upper surface of Lepidopteris baodensis sp. nov. Specimen PMOL-B01216.

Figure S2 Cuticle of the lower surface of Lepidopteris baodensis sp. nov. Specimen PMOL-B01216.

The supporting information is available online at csb.scichina.com and www.springerlink.com. The supporting materials are published as submitted, without typesetting or editing. The responsibility for scientific accuracy and content remains entirely with the authors. 